The last section on skin complications covers a wider field than is usually encompassed by the

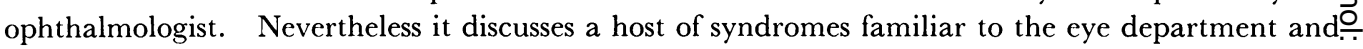
describes not only their dermatological manifestations clearly and concisely but also the pathological and immunological aspects which in many cases are still not fully understood and remain sub judice $\stackrel{5}{\rightarrow}$

There is an excellent bibliography and a workable index. The reader cannot fail to be impressed with the knowledge, which is being gradually wrested from nature, concerning immunological prob-⿳亠丷厂巾 lems and at the same time to be made aware of the gap which has still to be bridged.

A Handbook of Ophthalmology for Developing Countries. By G. G. Bisley. $\overrightarrow{0}$ 1973. Pp. I42, 32 figs, 16 plates. Oxford University Press, London. (£ 1.25)

In tropical and subtropical countries disorders of the eye are among the commonest of ailments needing treatment, and the blind in Africa number about 5 million, most of the cases being preventable Yet in North Nigeria, for instance, there is only one ophthalmologist to every ro million of the popu-:lation (in the U.S.A. there are 350). The paramount need is thus not for a limited number of expensively trained ophthalmologists, but for an army of orderlies, students, or nurses, who after a short training in basic medicine and ophthalmology can be quickly deployed into the neglected rural areas.

Dr. Geoffrey Bisley has a distinguished record in this field. After 26 years in Government Service in Kenya, where he directed one of the most efficient ophthalmic centres in Africa, and where heZ inaugurated an excellent system of mobile eye-units (which has been the envy of many less fortunate communities), he clearly appreciates the problems and needs of such underdeveloped lands.

This is an admirable book, since it is almost unique in covering the special requirements of such $\mathrm{a}$ 迎 practical, but limited, ophthalmic service. It is well written, with very clear diagrams, giveso $\overrightarrow{0}$ balanced account of basic ophthalmology, with special emphasis on tropical ocular infections simplified cataract camps, and so on; the final chapter (by Dr. W. R. Burkitt) on rural ophthalmolog is excellent. Thanks to assistance from the Royal Commonwealth Society for the Blind, the book is also gratifyingly cheap.

Cataract Surgery and its Complications. By N. S. JAfFe. 1972. Pp. 41 7, figs, refs. Mosby, St. Louis; Kimpton, London. (£ $\left.19 \cdot 5^{\circ}\right)$

The management of cataract problems is discussed in a concise and helpful way. This is achieved by correlating pathogenesis, pathophysiology, and the clinical picture. The value of recent contributions to surgical technique is also discussed, and the author, drawing upon his large experience, has $\frac{0}{0}$. made a critical selection of important advances, although the technique of phako-emulsification has been omitted.

The layout is excellent but the percentage of histological illustrations seems excessive in a book dealing with surgical problems. The reader can, however, obtain an excellent and authoritative review of current thought on cataract extraction, methods of treatment, and the avoidance of com- 5 plications. This type of review has not been covered recently by books devoted to the description $\rightarrow$ of operations and it is therefore to be welcomed.

Mikrostrabismus. Die Bedeutung der Mikrotropie für die Amplyopie, für die Pathogenese des grossen Schielwinkels und für die Heredität des Strabismus. By J. Lang. 1973. Pp. I 2 I, 39 figs, I 68 refs. Enke, Stuttgart (Buchesei des Augen-60 artztes No. 62). (DM29)

The author defines microstrabismus as a squint of less than 5 degrees with anomalous retinal correspondence-a sensory rather than a motor disturbance.

He deserves credit for stressing the importance of this condition, which had been previously $\underset{\mathbb{D}}{\circ}$ diagnosed as amblyopia without squint. Such an error was understandable as the cosmetic defect $\stackrel{?}{\circ}$ 
was hardly noticeable. Examination with the visuscope shows that there is a primary form of microstrabismus, which may develop into macrostrabismus, and a secondary residual strabismus resulting from surgery and orthoptic treatment of a higher degree of squint. Heredity plays a significant role.

The author considers microstrabismus to be a separate entity. To an oculist, who has been imbued with the teaching of Worth, microstrabismus is evidence of fusion deficiency. Even when the images presented to both eyes are superimposed by prisms, no perfect vision results. Failure to obtain normal binocular vision may be compared with the failure of speech training to produce normal natural speech.

\section{Corneal Preservation. Clinical and Laboratory Evaluation of Current Methods.} Edited by J. A. Capella, H. F. Edelhauser, and D. L. van Horm. i 973. Pp. 336, figs, refs. Thomas, Springfield, Ill. (\$22.50)

This book is a precis of the proceedings of a Symposium held in Florida in 1970. Its coverage is thus wider than its title suggests, but it has all the disadvantages of multiple authorship (33 contributors covering only 317 pages), with varying quality, overlap, etc.

Many interesting and useful points emerge, and excellent advice is given concerning the collection of eyes and simple inexpensive containers for transport. Many methods are described of evaluating corneal donor material. Some of these are still experimental, such as the reversal of induced hydration, electron microscopy of endothelium (mitochondrial changes), Stocker's trypan blue test, temperature reversal, nitroblue tetrazolium (where one eye has to be discarded), and studies with the specular microscope of Maurice; the last seems to hold most promise, since endothelial cells can easily be seen at about $100 \times$ with a $10 \times$ air-immersion objective.

There are some surprising statements. It is noted that the eyebanks of Canada, Brazil, Argentina, Israel, and France deep-freeze eyes, but there is no reference to the centre where this technique was first elaborated; and although credit is indeed given to the Westminster Hospital unit for the first use (in 1964) of deep-frozen material, this is said to refer only to rabbits (although the quoted title specifically mentions "human corneae"!) It is also curious that, although 55 per cent. of surgeons will not use eyes from jaundiced patients, only 57 per cent. refuse corneae from patients with absolute glaucoma.

The regular use of stored deep-frozen corneae is, in fact, limited to those few centres where an adequate supply of fresh tissue cannot be obtained, and for the occasional lamellar keratoplasty; but if recent work on the value of tissue-typing in corneal grafting can be confirmed, it may be necessary to have an eye-bank where one can call for the appropriate tissue match. In any event, this is a valuable compilation of our present (or at any rate 1970) knowledge.

Die Funktionsprüfung bei dichten Medientrubüngen des Auges. By D. W. Comberg and W. Ehrich. I 973. Pp. 75. 43 figs, refs. Thieme, Leipzig. (2r.goM)

The authors of this monograph are of the opinion that the conventional tests of ocular function in the presence of dense opacities of the refractive media are inadequate. A quantitative evaluation of the light sense through closed lids is required. The visual fields should be examined by eliciting phosphenes from pressure and diascleral light stimulation of the retina, and by testing the retinal vessels with the Purkinje vascular shadow figure. The technique of these tests and their reliability are discussed in great detail. Special stress is laid on examinations which can be easily done by the ophthalmic practitioner. No mention of echography is made. It is true that ultrasound is an anatomical and not a functional investigation. However, anatomy and function are so closely connected that this relationship would have been worth a few words of comment. 